\title{
Discipline and discretionary power in policing homosexuality in late Imperial St. Petersburg
}

\author{
Author: \\ Dr. Olga Petri \\ Leverhulme Trust Early Career Fellow \\ Department of Geography \\ University of Cambridge \\ Downing Place \\ CB2 3EN \\ Cambridge \\ UK \\ +447447540971 \\ op257@cam.ac.uk
}

\section{Acknowledgements:}

My gratitude goes out to Philip Howell, Stephen Legg, and Dan Healey for their meaningful engagement with my work. The paper benefited greatly from in-depth comments from two anonymous reviewers. I also would like to thank Ethan Pollock, David Beckingham, and Lesley Steinitz who read the paper on various stages and gave me very valuable feedback. Emmanuel College and the Department of Geography, University of Cambridge, generously supported my trips to St. Petersburg and Moscow to conduct the archival research for the paper. The results of my archival research owe much to the generous help of the staff of the Russian State Historical Archive in St. Petersburg (TSGIA SPB).

\section{Disclosure statement:}

No potential conflict of interest was reported by the author.

\section{Abstract:}

This paper explores queer sexual policing in late Imperial St. Petersburg (c.19001917). The focus is on the street-level constables who bore the principal responsibility for policing male homosexual offences in the city's public and semipublic spaces. This emphasis on the street-level policing of homosexuality contrasts with other discussions of gay urban history and the oppression of queer men by the authorities. The paper draws on new evidence from precinct-level police archives to complement and challenge previous discussions of queer sexual policing in the 
Imperial capital. By taking the fate of queer men in a autocratic city, this paper refines our understanding of the ways in which homosexual practices and identities emerged in modern times. Specifically, it builds on Michel Foucault's descriptions of constables as 'arbiters of illegalities', where the term 'arbiter' suggests rule-based and yet discretionary coercion. Here, the influential model of disciplinary policing of sexuality is complemented by an emphasis on the role of discretionary power in the history of homosexuality.

Keywords: Queer sexual policing, queer urban history, disciplinary society, late Imperial St. Petersburg, selective control of urban space, administrative history.

A running head: Queer sexual policing in late imperial St. Petersburg. 


\section{Discipline and discretionary power in policing homosexuality in late Imperial St. Petersburg}

On 25 September 1900, at two o'clock in the morning, a middle-aged, unemployed peasant from the Vitebskaîa region, one Ludvig Adamovich Zimmel, was arrested on Nevskiî Prospect, in the heart of late Imperial St. Petersburg (Tsentral'nyî Gosudarstvennyî Istoricheskiî Arkhiv, Sankt-Peterburg (TSGIA SPb) F.956, o.1, d.1614). His arrest was hardly unusual: this part of Nevskiî Prospect was frequently mentioned in the police logs of the adjacent boroughs in connection with a range of recorded offences. Men and women were arrested there almost every night for purported offences against civil statutes, including sexual activities such as prostitution, though they were usually released without charge (TSGIA SPb, F.1648, o.1, d.418, 1910; TSGIA SPb, F.965, o.3, d.72, 1904). The story of Zimmel, however, is unusual, and in two ways. Firstly, his punishment was exceptionally harsh: Zimmel was barred from residing in the city for two years. Secondly, an anonymous letter links his arrest to the phenomenon of queer cruising or male prostitution (TSGIA SPb, F. 956, o.1, d. 1614, p. 2). A series of diary entries, recorded a few years later, contains descriptions of meetings between queer men in a park just a few blocks away from the scene of Zimmel's arrest. However, these men did not seem to fear arrest. On one occasion, in May 1906, a group of men who the diary's author believed were obviously recognisable to constables as queer from their behaviour and appearance, were pictured as sufficiently impervious to police persecution to tease nearby constables and passers-by (Kuzmin, 2000, p. 158).

The background to the starkly contrasting responses of the constables ${ }^{1}$ in these two instances are the focus of this paper. I argue that the different responses of the police on the street is symptomatic of an evolving compromise between a vision of spatial order pursued by the city's governing hierarchy and the inevitable incursion into this order of behaviours wholly incompatible with this vision. One possible explanation for the differences in the outcomes of these situations might be changes in policing between the two incidents (for discussions of possible changes in attitudes and enforcement patterns in Russia around 1905 see (Engelstein, 1992; Karlinsky, 1989; Surh, 1989)). Remarkably, however, the elaboration of an 
alternative explanation founded upon an understanding of the role of constables in negotiating, interpreting and operationalising the terms of a compromise between order and transgression has not been a priority for historians of policing and the queer milieu in late Imperial St. Petersburg or in Russia as a whole. This paper argues that the development of models of policing that are reflective of the agency of members of the lower-level police hierarchy is overdue when it comes to understanding the projection of power in the late imperial city and its impact on homosexual men. In looking at day-to-day queer sexual policing, I use Michel Foucault's term 'arbiter of illegalities' to describe the role of street-level constables vis-à-vis the queer milieu (Foucault, 2015). The term 'arbiters', rather than lawenforcers, emphasises the possibility of rule-based and yet highly discretionary street-level sexual policing

In the academic literature on policing of queer men in historical settings, police activities related to queer cruising, sex and socialisation have usually been investigated using the prisms of well-maintained court-room evidence, medicoforensic reports, published diaries or memoirs, and newspaper clippings, while, at least in the case of St. Petersburg, other sources have remained largely untapped. Precinct-level archives are one such source, upon which this paper draws extensively. These consist of patrol and arrest logs, interrogation protocols and administrative correspondence. The study of these archives is challenging, as they are fragmentary, poorly indexed and largely composed in difficult-to-read administrative shorthand. At the same time, their painstaking exegesis offers perhaps the only opportunity to examine an important part of day-to-day policing routines.

On the basis of my analysis of newly discovered evidence contained in the surviving precinct-level police archives, I argue that day-to-day policing in the case of St. Petersburg is likely to have involved continued use of nuisance laws to uphold a historically largely forgotten regime of spatial order with regard to queer practices. This regime involved the exercise of police discretion and can be plausibly reconstructed based on the limited surviving evidence of cases likely to have been connected to queer spatial practices in the city. I refer to this regime as one of "queer sexual policing", by which I mean police activity directed at the surveillance 
and curtailment of sex between men and behaviour understood as a precursor to male sodomy, such as socialisation in bathhouses, private apartments, public parks, busy streets and commercial venues. Queer sexual policing is particularly revealing of the range and modalities of informal policing, as it addressed the liminal space between law and lawlessness, taking into account the obvious difficulty of detecting actual breaches of sodomy laws. ${ }^{2}$ Understanding and providing plausible interpretive models of the modalities of police responses in queer sexual policing helps us understand how a vision of spatial order held by the city's administrative elites was operationalised on the streets.

This choice of sources and method of analysis may prove relevant for the historical investigation of queer sexual policing in other cities as well, as it has the potential to reveal an unrecognized body of cases, which were not recorded as presumed breaches of laws explicitly directed at queer socialisation, cruising, prostitution or sex. Even today, these cases cannot be definitively linked to such activities, but I believe their study, albeit challenging and contingent, is of paramount relevance to understanding queer sexual policing, as they may represent the majority of contacts between representatives of state authority and the historical queer urban milieu.

This focus on constables on the street needs to be defended. Louise McReynolds usefully suggests that the first task of the Petersburg writers is to resolve this antagonism [between the state and an individual], to accept that the city helps to shape the individual' (Louise McReynolds, 2007, p. 861). ${ }^{3}$ This applies to constables as well. Constables were on the one hand subjects to the visions of public order communicated by their superiors and expressed in legislation, but on the other hand were the very agents charged with establishing and maintaining this order (Chauncey, 1994; Cocks, 2003; Cook, 2003; Croix, 2012; Houlbrook, 2005; Maynard, 1994; Peniston, 2001). To eschew situationally expedient simplifications that may prejudice our understanding of the projection of state authority onto urban space in the late imperial city, we need to avoid the reductionist notion that the aspirational role and function of constables in the administrative hierarchy was analogous to that of a gearbox or transmission system. In particular, there is a tendency in the historical writing about the police in St. Petersburg to interpret laxity or 
inconsistency in the enforcement of laws as indicative of either tolerance or inefficiency, analogous to grit in the gears. As Neil Weissman writes, 'at a time when the government was unable to construct a more effective centralised force, this outlook limited the ability of the police to interact constructively with the populace and, perhaps, contributed to the ultimate collapse of the regime'(Weissman, 1985, p. 68). Indisputable as the historical outcome may be, Weissman's characterisation of tsarist policing relies on his review of the broad parameters of the police organisation and its public perceptions. Looking at the surviving evidence of day-today police activities in a challenging discipline such as queer sexual policing creates a complementary empirical basis to test the alternative hypothesis that constables, in apparent recognition of their limited influence on transactions between individuals in the public domain, found ways all the same to negotiate a broadly consistent mandate and selectively project a vision of sexual order onto the city's spaces.

To present this argument, the first section of this paper describes the ambiguous relationship of constables and street-level policing to anti-sodomy legislation. I explain what I believe are the limitations of previously deployed empirical approaches to the analysis of queer sexual policing in late Imperial St. Petersburg. The second section focuses more specifically on the difficulty of using law enforcement as a proxy for policing in late Imperial St. Petersburg and I suggest an alternative approach. I ground my analysis in various newly discovered archival stories regarding situations in which constables employed discretion to manage the city's public spaces. Here, I also suggest a way of interpreting these sources and studying police activities targeted at homosexual socialisation by using Michel Foucault's term 'arbiters of illegalities' (Foucault, 2015). The third section explores the relationship between constables, subjects of policing and the police hierarchy by looking at major urban government attempts to regulate homosexuality in the city. The secret directive of 1910 illustrates how constables resisted expanding the spatial remit of their mandate in queer sexual policing. The last section of the paper positions constables' actions and their reflexive relationship with the police hierarchy in a broader discussion about a sexual 'economy of illegalities'. In this manner, I hope to resolve an apparent contrast between abstracted versions of Foucauldian coercive policing and a historical view of the tsarist police in late 
Imperial St. Petersburg as inefficient and 'tolerant'. These apparently contrasting situations are reconciled within a model of queer sexual policing, in which constables exercised a degree of coercive power precisely by making compromises tailored to particular situations and de-centrally negotiating their mandate both with their subjects and their superiors.

\section{Section 1. The city, constables and anti-sodomy laws}

The city and anti-sodomy laws

A central piece of legislation applied to and in the city was the Criminal Code (Ulozhenie o Nakazaniîakh Ugolovnykh i Ispravitel'nykh, "Code") issued by imperial decree in 1845, modified in 1857, 1866, 1885, 1906 and 1909 and still in effect until 1917. This Code specified as criminal offenses both bestiality and sodomy, the latter defined exclusively as anal intercourse between men. Article 995 of the Code stipulated a prison term of four to five years for men convicted of 'sodomy, a vice contrary to nature' (protivoestestvennyî porok myzhelozhestva) (Gromov, 1909, p. 280). The next article of the Code, Article 996, raised the penalty to imprisonment with hard labour for nine to twelve years, if anal intercourse between men was accompanied by the use of violence or performed with an underage or mentally defective man. Lesbianism, by contrast, was not a crime under tsarist law.

Article 995, like Article 175 in Germany or Section 11 of the 1885 Criminal Law Amendment Act in the UK, formally criminalised only a specific sexual act. Significantly, however, there was no legislation explicitly directed at cruising or male prostitution, as there was in the British Vagrancy Law Amendment Act of 1898, which referred to 'men who in any public place persistently solicit or importune for immoral purposes' and was, according to Matt Cook, instrumental in 'criminalis[ing] a putative homosexual identity' (Cook, 2003, p. 44). In St. Petersburg, the timehonoured criminalisation of sodomy was not matched by a legislative machinery that targeted the ways in which homosexual men met each other in the city's streets and public spaces. 
Given the well-recognised challenges of detecting consensual sex between men $^{4}$, this left St. Petersburg police with an inadequate legal arsenal to address activities such as cruising and male prostitution in the city's public and semi-public spaces. This challenge was not unique to St. Petersburg, nor was the fact that the city's police were forced to improvise. In Berlin, for example, Robert Beachy writes that police 'found creative methods for enforcing the German anti-sodomy statute, Paragraph 175' (Beachy, 2014, p. xvii). Beachy usefully highlights one particular event where such methods were used: a raid on Steeger's restaurant, which was a well-known queer site. The men in the restaurant on the night of the raid in 1885 were arrested, prosecuted and sentenced to between three and four months in prison for 'disturbing the peace', rather than for an offence against any laws or regulations specifically targeting homosexual sex, cruising or socialisation (Beachy, 2014, pp. 43 - 45). Nevertheless, this raid is described by Beachy as a singular and unique event, one that merely inaugurated an era of general police tolerance towards public cruising and the visible manifestations of the city's queer milieu in certain venues and at certain events. Beachy cites historical evidence that this tolerance was imperial policy in the German capital, or at least passively condoned by the highest administrative authorities.

No such tolerance can be assumed in the Russian capital. St. Petersburg was different insofar as no positive evidence of a regime of tolerance with regard to publicly visible instances of queer socialisation has been produced. As Laura Engelstein explains, legislative support for anti-sodomy legislation remained strong right to the end of the imperial era (Engelstein, 1995, p. 158). Moreover, as evidence published for the first time in this paper suggests, the city's highest administrative authorities, the police chief's and the mayor's office, initiated an effort similar to that carried out in Berlin for setting up a register of suspected homosexuals and ordered the expansion of queer sexual policing into the spaces of private apartments, where consensual homosexual sex was presumed to take place. These and other initiatives, which have not been part of the historical discourse surrounding late Imperial St. Petersburg's queer milieu, indicate that constables were expected to and did respond to immoral behaviours presumed to demonstrate a propensity to engage in homosexual sex, but which were not themselves a breach 
of anti-sodomy laws. This required constables to use the law 'creatively', as the bulk of detectible queer behaviours did not fall within the narrow remit of anti-sodomy laws.

Finding queer sexual policing

A historical analysis of queer policing in Imperial St. Petersburg, therefore, must take into account that constables were, at times, expected to respond to behaviours that were not, in themselves, illegal. Importantly, capturing this aspect of policing requires a shift of emphasis away from the analysis of well-documented cases in which men stood accused of breaching sodomy laws. If we base our understanding of the policing of homosexuality only on such cases, we are likely not only to misunderstand the nature of queer sexual policing, but also to underestimate the challenges faced by queer men and adopt a misleading conception of toleration of homosexuality in the historical city. This is an instance, where for historians of homosexuality methods can significantly prejudice perceived outcomes. How then can we study this type of policing?

With regard to St. Petersburg, a limited degree of attention to evidence of day-to-day policing - combined, perhaps, with complacency in implicitly assuming a model of policing according to which constables were more or less competent, numerous and corrupt executors of official orders and enforcers of written laws and regulations - has meant that the focus of the historical discussion of queer sexual policing has not been on the business of street policing, but rather on laws against male sodomy, court cases, medical reports, biographical information about queer men and the deficiencies of the tsarist police organisation more generally. In their pioneering works, Healey and Engelstein uncovered a great deal about sexuality in fin-de-siècle Russia and St. Petersburg in particular. They have shown the complexities of the legal framework and the difficulties of enforcing sodomy laws. They reached their conclusions based primarily on published material and, consequently, have more to say about the law in theory than about the day-to-day process of interpreting and enforcing those laws on the street. They used reports commissioned by the government, case compendia thematically compiled by 
contemporaries, medical and medico-forensic testimony and treatises, laws and court documents, as well as biographical information regarding several prominent homosexuals. Dan Healey (2001), for instance, cites the medico-forensic works of Bekhterev (1915), Merzheevskiî (1878), Serbskiî (1900), Obolonskiî (1898), Tarnovskiî (1885), and among legal works those of Nabokov (1903), Fuks (1914), Pîatnitskiî (1910 ); Laura Engelstein $(1992,1995)$ in her work relied on many of the same materials including Nabokov, Tarnovskiî, and Merzheevskiî.

All of these sources are more than a few steps removed from day-to-day street-level policing and may tell us more about the evolution of legal and medicoforensic notions of homosexual acts and identities held by the administrative elite than they do about the application of state power to deviant spatial practices, such as cruising. Dan Healey, for example, concludes that 'Russia's low incidence of sodomy prosecution moderated any nominative effects, which constant police attention directed at the stigmatized group had produced in Germany and France' (Healey, 2001, p. 83). He expands on this conclusion by arguing that in contrast to the surveillance routines typical from the mid-nineteenth century in Paris and Berlin, Russian police devoted little energy to this crime. Given that "the intimate character of homosexual actions makes these relations virtually undetectable," only a handful of cases went to court. [...] Article 995 against voluntary sodomy was virtually a dead letter in the largest of Russia's cities by the end of the Imperial era' (here Healey cites a contemporary lawyer losif Fusk (2001, p. 95)).

Given the inherent difficulties of using these sources and the existence of viable alternatives, historians of queer urban sociability and sexual policing in other cities have sought to expand their evidence to other sources. Cook, for example, argues for the need to look at day-to-day police routines in trying to reconstruct the workings of the historical queer milieu, but chooses to analyse this in his chapter on policing based almost exclusively on courtroom evidence from cases explicitly involving a presumed pursuit or consummation of homosexual sexual contact between men. He addresses this by supplementing evidence of court cases drawn from the administrative record with newspaper clippings concerning the same cases. In part, this may be justified by his regional and chronological focus, as he refers primarily to Britain and the period following the passing of the Vagrancy Law 
Amendment Act. During this period, in Britain queer men could be arrested and successfully prosecuted under laws banning men from importuning for immoral purposes, without the requirement to prove an incident of sex between men had taken place. And yet, in a revealing aside, Cook acknowledges that the police had previously used nuisance legislation to prosecute supposed homosexual behaviour', without describing such practices in detail or demonstrating that they were effectively discontinued following the introduction of the Vagrancy Law Amendment Act (Cook, 2003, p. 43). Similarly, Matt Houlbrook in his discussion of queer policing in London during the period between 1918 and 1957 draws attention to the deficiency of court room evidence, claiming that it does not sufficiently highlight the complex and often contradictory ways in which legislation was implemented' (Houlbrook, 2005, p. 20). And yet, he also eschews any concerted attempt to uncover the 'underbelly' of historical cases involving statutes other than those specifically targeting the pursuit of homosexual sex, cases, which were thus never explicitly linked to queer identities or activities of the persons involved. Such cases, however, may offer unique insight into the famously hidden histories of homosexuality.

Broadening the scope of investigation into historical queer sexual policing beyond cases, in which a breach of sodomy laws was documented, involves taking a closer look at the decisions taken in everyday policing shifts constables into focus and requires us to consider sources, which can tell stories about the often incongruent realities confronting constables on the beat. ${ }^{5}$ I complement the sources used by other scholars of tsarist policing and the relationship between the Russian state and queer men with a review of the fragmentary evidence of day-to-day policing in the capital. Much of this evidence is kept in municipal archives. ${ }^{6}$ These archives contain patrol and arrest logs, interrogation protocols and administrative correspondence. They are fragmentary and poorly indexed due to the destruction of police archives in February 1917 and during the turbulent first half of the twentieth century. ${ }^{7}$ It is virtually impossible to reconstruct any pattern in this destruction, making it very difficult to determine whether any biases have been introduced in the record as its result. I have worked on the assumption that the surviving sample is representative. Moreover, this sample poses considerable impediments to scholarly 
review. The small surviving fraction of records is contained in poorly catalogued files composed mainly of unsorted fragments in stenographic shorthand wrapped in packages with titles such as 'Third Police Precinct, June-December 1908'. The implication of the destruction of much of these archives and their relative inaccessibility is that it is highly unlikely that the complete documentary record of a single case can be reconstructed from arrest to sentencing. Hence, case records are always fragmentary in nature, and one must treat these fragments with the knowledge that any conclusions drawn from them may be demonstrably plausible, perhaps even likely, but cannot usually be definitively established, insofar as the cases relied upon may have taken unexpected turns not reflected in the remaining portion of the archival record.

Notwithstanding these limitations, I became acutely aware as I worked with these sources how poorly the fragmentary spatial stories they revealed lent themselves to interpretation vis-à-vis a narrative of gay 'oppression' or general, tolerance. I recognised that much of the nuance and inherent ambivalence contained in these materials would be lost by casting my research questions in terms of locating St. Petersburg on a linear spectrum between oppression and tolerance. Instead, I gained an understanding of some of the ways in which governmentality, using Michael Foucault's term, functioned with regard to a negotiation over the city's queer spaces. In practical terms, this meant, for example, avoiding first impressions about the implications of documents produced by and for the city's administrative apparatus. Specifically, in a time and place, where sex between men was a criminal offense, once a specific suspicion regarding such an offense had been recorded, constables on the case were placed in the uncomfortable position of having to manage trade-offs between the risks inherent in unsuccessful persecution or an insufficient response to possible breaches of law. Take for example, a case from 1901 concerning Lieutenant Raîkovskiî, who was accused by a former lover in a letter to the Criminal Investigation Department of having committed sodomy. A constable interviewed the yard-keeper of Raîkovskiî's apartment building and decided to close the case, noting that Raîkovskiî 'does not have visitors, and rarely goes out', 5 v (TGIA SPb, F. 965, o. 1, d. 1862, 5v). Closure of the case cannot be interpreted as evidence that Lieutenant Raîkovskiî had not breached sodomy laws, 
but may simply indicate that the constables asked to investigate concluded that persecution was not viable.

At the same time, in police and other administrative correspondence related to sex between men, the need to enforce the law was not subject to debate or question - at least not explicitly. Does this mean that queer men were effectively 'oppressed'? It is hard and perhaps impossible to answer this question, as any answer depends on a comparison of statistically relevant quantitative evidence between cities. The archival research leads me to conclude that such a comparison cannot be robustly conducted in the case of St. Petersburg. Conversely, however, arguments making the case for a historical view of St. Petersburg as a 'tolerant' city must also be treated with extreme caution, as they rely on the scarcity of instances of successful prosecution under laws banning sex between men, in some cases comparing acquittal rates between cities (Healey, 2001, p. 92). The poor state of the municipal archives means that this evidence cannot be relied upon as statistically definitive. More importantly, the evidence still contained in these archives does provide sufficient grounds to refrain from interpreting the apparent scarcity of court cases regarding consensual sex between men as unambiguous evidence of a general regime of police tolerance or indifference towards queer men and behaviours.

On the pages of these fragmentary documents, constables emerge as arbiters endeavouring to achieve a balance between the vision of public order they attributed to their superiors, and the often incongruent realities confronting them on their beat. Archival materials about policing reveal a nuanced picture, one that repositions late Imperial St. Petersburg's policing practices vis-à-vis similar practices in the West. This revision then shows that the way order was maintained or established on the street did not always correspond directly to the ways that laws were devised in government buildings. In the next section, I choose the term 'arbiters' to describe constables in late Imperial St. Petersburg, in explicit contrast to the more modern term 'law enforcement agent'. This choice of term, I believe, appropriately reflects to the possibility of rule-based and yet highly discretionary street-level sexual policing and can facilitate qualitative insights into the decisions of constables in the course of street-level policing. 


\section{Section 2 Subtle distinctions: law enforcers or 'arbiters of illegalities' in queer sexual policing}

The analysis of street-level police documents is a prerequisite for understanding how the projection of spatial order affected the city's queer milieu. The role of constables in effecting this projection is, perhaps, best captured by Michel Foucault's term 'arbiter of illegalities'. The term 'arbiter' emphasises systematic and yet discretionary street-level sexual policing. In the context of queer sexual policing this projection of order entailed not only police activities directed at the curtailment of sex between men, but also the surveillance and encumbrance of behaviours understood as a precursor to male sodomy, such as socialisation in bathhouses, private apartments, public parks, busy streets and commercial venues.

While the police in late Imperial Russia have typically been described by historians as a mixture of overbearing and incompetent (Daly, 2004; Hasegawa, 2017; Weissman, 1985; Zuckerman, 1996), an emphasis on the modalities of precinct-level police responses to both events on the street and impulses from members of the city's administrative lends credibility to an alternative view of queer sexual policing. I suggest that queer sexual policing was broadly consistent in the application of discretion and, thereby, potentially more effective than previously assumed in managing public spaces with limited police resources. The surviving evidence may not allow historians to fully elaborate or definitively establish such an alternative view, but, as mentioned above, it does make it more difficult to interpret the scarcity of court cases under sodomy laws as compelling evidence of a general regime of police tolerance or indifference towards queer men and behaviors (Healey, for example, writes 'tsarist policing of the prohibition would be sporadic or indifferent' (2001, p. 92); see also (Engelstein, 1995, p. 158)).

The pioneering works of Dan Healey provide insightful elaborations of what he describes as a regime of 'euphemism and discretion' in policing 'sodomites and tribades' in late Imperial Russia (2001, p. 77). Here the term 'discretion' appears to refer to the discrete treatment of the issue of sodomy in the public and legal discourse of the time, as well as cover-up surrounding certain instances of male homosexual sex involving prominent members of the imperial capital's elite. He does not use the term as I do to describe de-central decision-making by constables. 
Healey concludes that laws against consensual sex between men were 'virtually a dead letter in the largest Russian's cities by the end of the Imperial era' (2001, p. 95).

At the same time, Healey makes several ambiguous observations, which are equally consistent with a general regime of police tolerance or indifference towards consensual male sodomy, as with a locally idiosyncratic and selective regime of coercion. Firstly, he points out the greater willingness of Russian members of the medical professions than their Western counterparts to acknowledge the limited relevance of their expertise for prosecution under sodomy laws (2001, pp. 81 - 92). However, he does not link the comparatively lower pretence of and reliance upon medico-forensic expertise to another circumstance, to which he explicitly draws attention: that is, that medics provided this expertise to Russian courts free of charge, in contrast to the West, and therefore had less incentive to boost its perceived value (2001, p. 82). Healey further observes that 'Russian psychiatric attention, when it was focused on the problem of homosexuality, rejected the full range of stigmatization when applying the discourse to women or members of the lower classes, out of sympathy with their subordination. Psychiatrists themselves suffered from the same subordination in the autocratic state' (2001, p. 92). There may be a simpler explanation: should not the absence of an economic incentive to expound medically tenuous conclusions and the potentially adverse reputational consequences thereof be considered an equally plausible motive to avoid unpaid work? If so, this would create a locally relevant and systematic impediment to court prosecution of sodomy, but not necessarily to other means of police coercion. Similarly, Healey points out that according to case compendia from 1910, 'the justice system prosecuted these cases much less successfully than the average crime, with only about 41 percent of sodomy indictments leading to conviction (compared with a conviction rate of 66 percent for all other crimes)', despite a dwindling number of cases brought for prosecution in the first place. In another passage he mentions as an aside that 'the autocratic state itself was inclined to apply administrative punishments that would obviate any courtroom session' (2001, pp. 94, 93). ${ }^{8}$ Might not these facts be causally connected? Might not the particularly low conviction rates for alleged sodomy have inclined constables and other state authorities to pursue alternative methods of policing the queer milieu? Healey's observations 
suggest that he is aware that in late Imperial Russia there may have existed alternative modalities of systematic state interference with the indiscrete pursuit of consensual sex between men and that these - perhaps to a greater extent than in the West - lay outside the scope of criminal prosecution. Nevertheless, Healey does not pursue the implied avenue of empirical investigation and analysis into the locally specific informal modalities of normative coercion by state agents. It is possible that such an investigation would have been a distraction from Healey's primary focus on the relationship between homosexual identity and law in revolutionary Russia. Nevertheless, his choice not to pursue this avenue of investigation limits his observations to what his evidence could support, and this seems to have been constrained by the very small fraction of cases brought to public or medical attention or trial under sodomy laws.

In writing about 'Soviet Policy towards Male Homosexuality', Laura Engelstein also acknowledges the limitations of the judicial record, but is more cautious in drawing conclusions from these limitations (1995). She writes that 'while few men were ever prosecuted in tsarist courts for the crime of consenting (homosexual) sodomy, it is not the case that imperial legislation, or even the dominant opinion among progressive legal scholars and lawmakers, exempted sodomy from repression. The tsarist regime was notorious both for ignoring the law (acting through imperial fiat or passing "emergency legislation" that superseded formal procedures and guarantees) and for laxity in implementing the laws it did endorse' (1995, p. 158). In her critique of the Foucauldian disciplinary hypothesis, Engelstein describes late Imperial Russia as a society in which liberal reforms aimed at establishing legally enforceable rights and obligations never progressed beyond the nascent stages. She writes that "here, the "reign of law" had not "already begun to recede", as Foucault said of the European nineteenth century, but had not yet arrived' (1993, p. 343). Rather, the tsar appropriated the institutional appurtenances of a rule-of-law state (legal codes, independent judiciary, trial by jury), while continuing to exercise absolute sovereignty through the mechanisms of an inefficient administrative state. This form of state order cascaded through the police hierarchy and influenced the way in which constables operated on a daily basis. 
Neil Weissman, in his work on 'Regular Police in Tsarist Russia, 1900-1914' is the only historian to have focused on the regular police and firmly positions the police as an extension of the administrative state (1985). He contributes some important observations about street-level policing, although, as indicated above, he seems to adopt a binary classification of police activity as either law enforcement analogous to contemporary progressive European examples, or, alternatively, chaotic and ultimately dangerous coercion. His fundamental conclusion is that the Russian police were chronically under-staffed, under-qualified and poorly supervised, even in the imperial capital. He does not see much merit in what he describes as the 'arbitrary and coercive operational style' adopted as an expedient among tsarist police $(1985$, p. 50). Like Foucault in his discussion of patchy law enforcement regarding the weavers in fifteenth-century France, Weissman unhesitatingly links this arbitrary and coercive style not only to structural constraints, but also to police corruption (Foucault, 2015; Weissman, 1985, p. 50).

Despite the fact that Weissman aptly and plausibly describes the deficiencies of the police organisation in the imperial state, he does not test his hypothesis regarding the catastrophic inefficiency of the tsarist police against the available evidence. He observes that 'the tsarist police were indeed universal administrators' distracted from their 'primary function of controlling deviance' (1985, pp. 56 - 57). Moreover, he cites police reformer V.E. Frish thus: 'they (the police) are unable to perform their central function of defending security and tranquility' (Weissman, 1985, p. 65). These observations remain equally untested, however, in specific instances of police activity, since Weissman's evidence is limited - as, perhaps, it must be in a broad review of policing across the empire - to aggregated statistics and secondary evidence of police inefficiency. He does not delve into the fragmented, complex and usually incomplete municipal case files to examine his hypotheses regarding the inefficiency and inconsistency of police coercion.

\section{Queer policing in action}

The above-mentioned arrest of Ludvig Zimmel and his severe punishment is, therefore, quite problematic for the historical consensus regarding inefficient, 
arbitrary policing and a supposed tolerance of activities linked to consensual homosexual sex (TSGIA SPb, F.956, 0.1, d.1614). His story, as well as those of many other men and women who were, like Zimmel, arrested on Nevskiî Prospect and in neighboring areas for various petty crimes, suggest that constables on the beat found a way to manage the urban fabric and curtail some behaviors associated with homosexual sex.

On 23 September 1900 the mayor of St. Petersburg, Count Kleigel, received an anonymous letter, claiming that 'last year a new class of debauchers joined those already populating Nevskiî Prospect - pederasts. One of them is a Polish man, who wears a brown coat and hat and frankly offers his sexual favors' (TSGIA SPb, F.956, $0.1, \mathrm{~d} .1614$, p. 2). The author went on to proclaim that 'there has never been such debauchery in St. Petersburg. The public cannot fight by itself' (TSGIA SPb, F.956, 0.1$, d.1614, p. $2 v-3)$. In response to this letter, as the archival file containing it further informs, not even two days later, on 25 September, at two o'clock in the morning, a peasant from Vitebskaîa region, Ludvig Adamovich Zimmel, a middleaged (37), unemployed man with a recognizably German name, was arrested on Nevskiî Prospect. The file makes no further mention of the color of his coat, nor anything particularly 'Polish' about him. Even the part of Nevskiî Prospect, on which he was arrested, Spasskaîa Borough, is not the one specified in the letter. It is possible that Ludvig Zimmel is not the man described in the letter, but simply a queer man previously known to the constables of the borough as a habitué of Nevskiî Prospect or one coincidentally observed by them that night and arbitrarily linked to the anonymous letter. In the absence of any information in the police file regarding Ludvig's activity at the time of his arrest, it appears that the anonymous letter along with the unstated and unsubstantiated judgement of certain constables linking Zimmel to said letter sufficed not just for his arrest and detention, but also for a ruling by the administrative court, which subsequently handled his case.

The case of Ludvig Zimmel demonstrates a crude kind of efficiency in speedily responding to a citizen's tip-off. Firstly, little more than a day passed between the receipt of an anonymous letter about a 'man, who wears a brown coat and hat and frankly offers his sexual favours' on Nevskiî Prospekt and Zimmel's arrest (TSGIA SPb, F.956, 0.1, d.1614, p. 2). Secondly, as the file regarding 'the pederast Ludvig 
Adamovich Zimmel' reveals, he was soon afterwards removed from the city, barred from returning for two years for the petty crime of 'soliciting members of the public' (pristavanie k publike) (TSGIA SPb, F.956, o.1, d.1614, p. 7, 10). Previously, he had served three months in jail for 'pandering stolen goods' (TSGIA SPb, F.956, 0.1, d.1614, p. 5v), making him a repeat offender under petty crimes statutes, which were subject to less demanding administrative procedures than offenses against the statutes of the criminal code, including sodomy (regarding prosecution for civil offences, see (Del, 1908; Gromov, 1909, p. 667; Kleîgel's, 1900; Volkov, 1914)). ${ }^{9}$ Following this second arrest he was banned from residing in the city for two years (TSGIA SPb, F.956, o.1, d.1614, p. 10).

Zimmel's story shows that the authors of the documents contained in this particular file had no qualms about recording, on the one hand, their determination that Zimmel was not only a pederast, but the pederast mentioned in the unspecific anonymous complaint, and, on the other hand, banishing him for a crime for which no evidence was recorded. The anonymous letter itself served as the only evidence in his file. While it is, of course, impossible to draw general conclusions on the basis of a single case, it is at least plausible that Zimmel's case was not unique - or rather, unique only in the sense that it has been preserved in its entirety and creates a documented link between allegations of homosexual cruising and/or prostitution and persecution under petty crimes statutes.

Cases in the police logs of arrests from Kazanskaîa Borough, to take one example, provide a helpful context as they contain an abundance of notes regarding arrests for loitering and soliciting, several of which indicate that the police's intention was, in fact, to tackle 'debauchery' (TSGIA SPb, F.1648, o.1, d.418, 1910). A few cases stand out as those of individuals engaged in prostitution: Elena Sazonova, for example, was arrested in 1910 on Voznesenskiî Prospect for 'loitering for the purpose of debauchery' (TSGIA SPb, F.1648, o.1, d.418, 1910, \# 113, p. 29). Not only was Voznesenskiî Prospect famous for prostitution, but the note taken together with the circumstance that she was arrested at one o'clock in the morning and sent to the Medico-Forensic Committee, an institution ambiguously tasked with both preventing prostitution and improving hygiene (Bernstein, 1995; Fedorov, 1896 ; Il'ich, 1907; Koffin'on, 1908; Ruadze, 1908), strongly indicates that Elena was a prostitute and 
connects her crime to sexual policing. In many other cases, women, who had been arrested were released in the morning after several hours' detention. The same procedure was applied with men, who were similarly arrested for loitering and soliciting. Most of them were eventually released without charges being brought against them (TSGIA SPb, F.1648, 0.1, d.418, 1910; TSGIA SPb, F.965, 0.3, d.72, 1904).

The existence of an anonymous letter in Zimmel's case uniquely links an otherwise inconspicuous civil offense to queer sexual policing. This case, along with an abundance of territorially consistent night-time arrests for similar crimes lends plausibility to the hypothesis that petty crimes statutes were applied by constables in fulfilling their mandate related to 'surveillance of common order in public places, markets, restaurants, pubs and similar places, everywhere, where anyone has free access', as instructed in the highly general terms of a contemporary police handbook (Budkov, 1910; Kleîgel's, 1905, p. 10; Obolenskiî, 1914; Obolonskiî, 1898). Similarly, article 43 of the administrative code bestows upon the police powers to intervene in cases, where constables observe 'impudent and seductive behavior in public places' (Gromov, 1909, p. 685). While the constables, who arrested Zimmel, acted with a certain efficiency and within their mandate, they exercised remarkable discretion in striking important compromises related to this case. The risks inherent in engaging in an unsuccessful prosecution were carefully brought into balance with the risk of leaving the anonymous letter, which had been passed down by the highest police authorities, without an adequate response. By forwarding the letter to the borough level, superior authorities may have intended to send a signal that visible, public queer behavior in central public spaces was to be addressed by police management of these spaces, and the existence of a complaint would have raised the urgency of this issue.

The practice of using petty crimes statutes to respond to visible sexual solicitation in the city's busiest commercial areas would be broadly consistent with the observation that few consensual sodomy cases were brought to trial. It would, however, complicate the supposed conclusion that the Russian capital's administrative hierarchy and police were not much concerned with curtailing consensual male homosexual activity. The practice in evidence in the case of Zimmel 
and, perhaps, also in the wider range of cases of containment of spatial practices presumably related to the pursuit of opportunities for male homosexual sex, may constitute the 'missing link' between the dearth of criminal cases related to consensual sex between men and the persistent intention at least among some members of the administrative elite, as Engelstein has described it, to subject sodomy to repression.

\section{Teasing constables}

Not always was the police's response to recognizable and visible queer behavior so swift and robust. Kuzmin, who I mentioned in the introduction to this paper, recorded an instance in May 1906, when he and his male friends 'teased constables' in the Tavricheskiîi Garden. (Kuzmin, 2000, p. 158). This public garden is a brief walk away from Nevskiî Prospect and was also famous cruising site (Healey, 2001, p. 32; Ruadze, 1908, pp. 105 - 107). It is clear from Kuzmin's diary entries that his group's behavior could be described as anything but discrete. According to Kuzmin's reports, he and his friends dressed extravagantly (Kuzmin, for example, prided himself in his instantly noticeable yellow shirt) and considered it quite normal and acceptable to hold hands with a lover during strolls in the Tavricheskiîi Garden in unmistakable reference to a sexual relationship (Kuzmin, 2000, pp. 176, 185, 217). It is clear according to Kuzmin's diary entries that he and his friends did not fear police interference in their activities, despite the fact that constables had options available to them, should they have wished to encumber queer cruising, as it might be described in today's language. Why then did Kuzmin and his friends not fear arrest?

There are at least two possible explanations. Both point towards a nuanced consistency in the application of discretion in queer sexual policing and the management of spatial order. One explanation is that Zimmel's and Kuzmin's behaviors may have fallen on different sides of unrecorded and historically difficultto-establish boundaries of accepted sexuality. In the case of Zimmel, who was arrested alone, at night-time and whose arrest was linked to a letter making reference to 'frankly [offering] sexual favors' (TSGIA SPb, F.956, o.1, d.1614, p. 2), the commercial element or prostitution may have been particularly pronounced, 
while in the case of Kuzmin and his friends, their interactions and flirtations in the Tavricheskiîi Garden seem to have been of a primarily social and non-commercial nature.

A more sinister interpretation would be that constables in the park acquiesced to a softening of the usual state monopoly on violent coercion, willingly sharing this power with another group, which was also well represented in the park: so-called 'hooligans'. This acquiescence may have been motivated by fear of trouble, a lack of resources or even corruption. It is likely that for at least some of the hooligans there was a commercial element to this power-sharing arrangement and this commercial element may have penetrated the queer milieu. Kuzmin recorded at least one instance in which a friend had sex with one of the hooligans and, similarly, he mentions interactions with hooligans, which indicate a degree of familiarity between these groups (Kuzmin, 2000, pp. 113, 159). It is not far-fetched to consider the possibility of regular sexual, and monetary exchange between hooligans and queer men of Kuzmin's circle, which may have been underpinned not only by desire and opportunism, but also by the threat of violence or exposure.

The reluctance of the police to interfere with the activities of hooligans in certain places in late Imperial St. Petersburg was identified by contemporaries and has been commented upon by historians. On one occasion described in Kuzmin's diary, constables looked on as he and his friends were harassed and beaten by hooligans near the Tavricheskiîi Garden (Kuzmin, 2000, pp. 164 - 165). On 12 June 1900 , the police investigative department received an anonymous letter, the author of which complained about a group of young men in the Tavricheskiîi Garden, who 'chose this garden as their regular meeting place and engage in various kinds of deviant behavior, theft and fighting', as well as drinking vodka with 'ladies of shady reputation' (TSGIA SPb, F. 965, o. 1, d. 1631, , 1900, p. 1; see also a contemporary newspaper article: (Peterburgskiî listok, 1909)). According to the author of this anonymous letter, policemen remained idle to such a degree that hooligans came to dominate parts of the garden. He wrote: 'Speaking in obscene and vulgar language, these hooligans could be counted upon to start a fight, if rebuked for such behavior' (TSGIA SPb, F. 965, o. 1, d. 1631, p. 1). The historian Joan Neuberger explains that hooligans 'eluded police control' in the city, as interfering with them could be risky 
even for armed constables. Hooligans were, according to this description, generally 'armed with daggers, brass knuckles, and small weights on strings (giri) that were twirled menacingly' (Neuberger, 1993, p. 26). It seems likely that the constables on patrol in the Tavricheskiî Garden recognized the garden as a functioning system that was to be interfered with only when certain boundaries were crossed. These boundaries do not seem to have included violence against queers or amongst hooligans themselves, as both groups seem to have been considered potential perpetrators against good order. It also cannot be precluded that hooligans shared the proceeds of their activities with constables. Regardless of whether constables were motivated by laziness, fear or greed, it is clear that Kuzmin's and his friends cruising as well as the various activities of hooligans in the Tavricheskiî Garden benefited from constables' predictably consistent exercise of restraint in applying their mandate of curtailing 'impudent and seductive behavior in public places' to the activities of both groups in this space (Gromov, 1909, p. 685).

In this section, I have drawn upon an analysis of instances of queer sexual policing from both well-known and new historical sources to introduce a model of policing, in which the largely systematic and consistent exercise of police discretion plays a central role and in which state agents can be described as 'arbiters of illegalities'. In the following section I further explore the relationships between constables, subjects of policing and the police hierarchy by looking at urban government initiatives to regulate homosexuality in the city.

\section{Section 3. The secret directive of 1910}

A secret mayoral directive sheds further light on the role of constables in interpreting and operationalizing the scope of police activities to curtail sodomy and queer socialization in the city's spaces. On 21 October 1910, the mayor and head of police, Count Vendorf, dispatched this directive to all police stations, requiring them to identify men suspected of engaging in homosexual sex in private apartments. The directive appears to reinforce a possible hypothesis that police hierarchies targeted the spatially ambitious enforcement of 'public decency and peace' by repressing male sodomy even in private residences. However, the responses from constables in 
various city boroughs cast a revealing light on the role of precinct-level policemen in negotiating the geographies of homosexual sex and cruising in the late Imperial city. The directive explicitly ordered constables to collect information about men living alone, who might be homosexuals:

\begin{abstract}
According to information, to which I have become privy, certain individuals, who have sufficient material means and live by themselves, receive regular visits from students of institutions of higher learning as well as other young men. These young men then engage in unnatural relations of homosexual intercourse with the hosts and with one another.

Given the need for determined action to protect our youth against the scourging influence of debauchery, I request you provide - within two weeks - detailed information about such individuals, who according to their behaviour give reason to suspect such inclinations.

The chief of the secret police is to render all necessary assistance to the boroughs in the execution of this order (TSGIA SPb, F.569, o.10, d.104, 1910-1914, 1910, \# 2199, pp. 189-90)
\end{abstract}

On the face of it, the directive delivered an unambiguous message to constables to be weary of individuals potentially willing to engage in homosexual intercourse, as a matter of course underscoring the stereotype of the debauched well-to-do male preying on young men. The directive also carried the potential to serve as formal grounds for intrusions by constables into private apartments. And yet, despite the extensive internal police correspondence it engendered, the directive cannot be causally linked to a single arrest.

An analysis of the responses from boroughs, precincts and 'watch areas', fortuitously filed along with a copy of the directive, strongly suggests that constables resisted this mandate. ${ }^{10}$ For example, constables from seven of eight precincts within the Spasskaîa Borough flatly denied the existence of any suspicious individuals of this sort in their precincts (TSGIA SPb, F.1648, o.1, d.1222, 1910, pp. 48-58). One went even further, writing that 'there are neither apartments, nor individuals who engage in homosexual sex' (TSGIA SPb, F.1648, o.1, d.1222, 1910, p. 55). The author of the Narvskaîa Borough's consolidated response flatly denied the presence in his borough of any individuals, 'who might give rise to the suspicion of engaging in the 
unnatural Greek vice', adding that in this relatively poor district 'apartments are rented by families and groups of individuals and their occupants and life-styles are well known to us' (TSGIA SPb, F.1648, o.1, d.855, 1910, p. 195). The Narvskaîa Borough's response is remarkable for its author's confidence - sincere or merely professed - that in the eyes of his superiors his generalised assertion of knowledge regarding the residents of his borough provided robust grounds for refraining from further action. Perhaps the most creative reply comes from the Liteînaîa Borough, in which a previously known suspect, titular counsellor Otto Tard'e, was redeployed as target for action under the directive (TSGIA SPb, F.1648, o. 1, d.651, 1906-10, 1910, $105,107 \mathrm{v}, 108,108 \mathrm{v})$. The ruse was quickly discovered, but without further consequence. The chief of police's office replied that Tard'e had already been arrested in 1909 'for indecent behaviour and solicitation with inappropriate proposal to Gerasim Adamov [a man]' and that no further action was required in his case (TSGIA SPb, F.1648, o. 1, d.651, 1906-10, 1910, 108v). The surviving responses do not indicate that a single previously unknown suspect was identified in response to the directive.

A modern-day reader of police documents may be tempted to see the reason for the directive's apparent failure to achieve its objective in its lack of instructive detail. Were constables free to ask questions and disclose their objective of searching for men suspected of having homosexual sex? What was the intended next step? Would men suspected of having homosexual sex be monitored, until adequate proof could be obtained, and then arrested? Were constables free to improvise other measures to prevent the gatherings described in the directive from taking place?

While the lack of detail regarding these questions may be jarring to a modern-day reader, the directive is no exception in these apparent ellipses. Contemporary police instructions are characterised by textual ambiguity and vague instructions, especially ones related to issues of sexual policing, suggesting that the higher charges of the police hierarchy conveyed the desired spatial order in quite general terms, leaving significant leeway to constables in interpretation and operationalization. For example, in July 1908, following incidents at the hotels Dunaî and Olimpiîa, in which the police conducted raids and discovered 'two men and two 
women simultaneously staying in a single hotel room for the purpose of debauchery', the same major-general Vendorf ordered his deputies to 'take measures to avoid allowing the likes of this in the future, in recognition of the circumstance that the concurrent inhabitation of one hotel room by several men and women is not aligned with the requirements of public order and decency' (TSGIA SPb, F.1648, o.1, d.651, 1866 - 1915, 1908, p. 112). Vendorf remained silent about the nature of the actions constables were to take in the absence of applicable legislation to prevent any recurrence.

Omission of instructive details in the directives of this time is consistent with the degree to which their author felt he could rely on constables to make their own prudent judgements regarding matters such as the sexual inclinations of the inhabitants of their boroughs and to come up with measures to achieve the desired objective. It is likely, therefore, that the reasons constables avoided implementing the directive by providing the requested lists and 'detailed information' lay beyond the text of the directive itself. One plausible explanation, which I propose here, is that the constables who responded to the secret directive were reluctant to expand their mandate of 'defending security and tranquillity' beyond prominently visible commercial or public spaces into private apartments.

While the historical record provides several indications, including the directive itself, that the vision of spatial order pursued by the city authorities was incongruent with readily recognisable male homosexual socialisation, resources for the implementation of this vision were deployed selectively. These resources included not only constables, but also building plans and regulation. The development of a prominent roofed gallery of shops, hotels and cafes off Nevsky Prospekt is a telling example. By the 1880s, the space, referred to in contemporary documents as 'Passazh', had become a widely recognised homosexual cruising site (Koni, 1912; Tarnovskiî, 1885). Constables and plain-clothed policemen monitored the Passazh and its facilities ((Gosudarstvennyî Arkhiv Rossiiskoî Federatsiii (GARF) F.111, o.1., d.2999, 1911); see also (Ruadze, 1908, p. 102)). However, it soon became apparent that the space in its original configuration with hotels and cafes accessible from a second-floor gallery with large open arches was nearly impossible to monitor and effectively police. Passazh offered too many avenues of discreet escape at 
moments' notice, while also providing quasi-panoptical visibility in immediately adjacent areas. In 1900, following the failure of policing to significantly curtail recognisable male homosexual socialisation and male prostitution, city authorities physically reconfigured the building. The public perception was that these spatial modifications were carried out to combat 'debauchery' related, in this context, exclusively to homosexual behaviour (while male homosexual prostitution in the Passazh is mentioned in several records, I found no evidence that this space was also frequented by female prostitutes in search of clients) (Peterburgskiî Listok, 1900b; Peterburgskiî Listok, 1901). The initial results were encouraging, although there is some indication that these measures were ultimately insufficient to eliminate visible cruising in this space. The city administration's efforts to eliminate cruising by police deployment and physical reconstruction of the Passazh indicate the lengths to which the urban authorities were willing to go to in selectively enforcing a vision of spatial order that was irreconcilable with what we would today describe as cruising (see discussion about the Passazh after the reconstruction in (Peterburgskiî Listok, 1901).

Another example of selective enforcement of a vision of spatial order incongruent with recognisable male homosexual socialisation and prostitution was the bathhouse ordinance of 1879 , revised in 1903, which included provisions to facilitate the policing of secluded chambers in the city's large commercial bathhouses (TSGIA SPb F.792, o.1, d.3337), this ordinance is discussed in Petri (2016)). Despite patchy enforcement, these broadly consistent efforts suggest an aspiration on the part of members of the city's administrative hierarchy to hamper homosexual socialisation and prostitution along with illicit heterosexual encounters by subjecting spaces presumably used for these encounters to surveillance and policing. The regularity and consistency of these efforts is not obviously compatible with the assumption frequently suggested or implied in the historical literature of a general regime of tolerance towards consensual male sodomy in Russia's capital during the late Imperial era.

At the same time, as discussed in the previous section, Mikhail Kuzmin's indispensable diary provides one of several credible accounts to suggest that these aspirations were only selectively operationalised by constables (Kuzmin, 2000, pp. $165,158,159)$. Healey's excellent work regarding the topography of homosexual 
prostitution suggests that enforcement was limited to certain areas and situations, which for some reason - be it an anonymous complaint, the proximity of prominent ministries or embassies, or interference with commercial interest - attracted the eye of urban authorities (Healey, 2001). In the resulting entente between queer men, constables and the broad class of governing agents, a remarkably stable topography of both homosexual prostitution and cruising emerged. As several police protocols and contemporary newspaper clippings suggest, this topography was known not only to constables, but to a degree also to members of the public (Peterburgskiî Listok, 1900a; Ruadze, 1908). As the correspondence engendered by the secret directive of 1910 suggests, constables played an important role in determining the scope of efforts to curtail sodomy and homosexual cruising.

Rather than stipulating a general regime of tolerance, however, the surviving evidence makes it plausible, and indeed likely, that the ambitious vision of spatial order indicated by this directive was systematically frustrated by the scope of the operational mandate accepted by street constables. This mandate was shaped not only by characteristics of the crime, as has been previously recognised ${ }^{11}$, but also by the negotiated and selective designation of spaces in which enforcement was possible. Against the background of this geographically selective spatial 'hygiene', the directive acquires three important dimensions worthy of emphasis. Firstly, as an expression of the expectations of the highest levels of the police hierarchy it demonstrates an ambition to expand forms of police surveillance and, possibly, enforcement to private apartments to undercut consensual male homosexual sex and socialisation. Secondly, it reinforces a historical understanding of policing in the late imperial city, according to which urban authorities relied heavily on the discretion of constables in determining which actions to take in achieving objectives of spatial order. Finally, and most importantly, the surviving correspondence indicates both the reluctance of constables to accept the implied expansion of their mandate, as well their superiors' lack of insistence. All three aspects indicate a degree of consensus within the police hierarchy about the scope of activities to be carried out by constables in selectively enforcing the vision of spatial order implied in the directive and targeted by other administrative efforts. 
In this section I explored the relationship between constables, subjects of policing and the police hierarchy by looking at the secret directive of 1910 . The responses to the directive, as well as omissions and ambiguity in the text of the directive itself, reinforce a view of the police in late Imperial St. Petersburg in which police discretion is an essential element of the projection of state power onto the city's spaces. Constables were expected to maintain an imprecisely specified, but relatively consistently understood degree of order on the streets and in apartments, hotels and other venues, and were free to exercise discretion in fulfilling their role as 'arbiters of illegalities'.

In the last main section of this paper, I ground my empirical analysis of the reflexive relationship between constables and the police hierarchy in a broader discussion about a sexual 'economy of illegalities'. In this economy, constables exercised a degree of power precisely by making compromises tailored to particular situations and negotiating their mandate both with their subjects and their superiors.

\section{Section 4. Police, the state and the projection of visions of order onto urban space}

The role of police discretion in selectively enforcing a vision of spatial order communicated to constables by their superiors suggests that the kind of negotiated, even complicit policing identified elsewhere, found its way into a regime where authoritarian ambition pragmatically arranged itself with constraints upon administrative resources. The resulting picture appears less chaotic than Weissman's analysis of the tsarist police's 'arbitrary and coercive operational style' and its revolutionary disintegration seem to suggest (Weissman, 1985). The theoretical frameworks proposed by Michel Foucault for the analysis of policing and surveillance in the workings of governmentality can be both challenged and adapted to help understand sexual policing targeting male homosexual sex and socialisation in late Imperial St. Petersburg. A simplified model of the disciplinary society, which pitches popular resistance against monolithic state oppression, can be constructively complicated by a nuanced view in which police discretion is indicative of a systematic compromise between state ambition, subjective police agency and the 
motives of regular subjects. The seeds of such a view can be identified in the work of Foucault himself, the proponent par excellence of models of the oppressive or insidiously manipulative disciplinary society.

According to Foucault, the deployment of specialised police forces contributed to the emergence of a disciplinary society (Foucault, 1978). The earliest, more tentative, versions of this thesis (later somewhat obscured in the published form of Discipline and Punish (Foucault, 1991)) linked these developments straightforwardly to the interests of the dominant class, in conditions referred to by Foucault as a kind of 'civil war', such that activities constituting a breach of law were efficiently identified and punished as both moral retribution and pragmatic deterrence.

Approached in this manner, the directive of 1910 looks like a classic instance of the disciplinary surveillance of sexual impropriety serving the persecution of queer men. Tempting as it may be to brush aside the broadly consistent responses from constables in boroughs and precincts as merely symptomatic of the poor state of the imperial police, I have proposed what I believe is a more compelling and contextually consistent interpretation of the evidence described above. It is important to state that this interpretation may not be necessitated by the available evidence, but is at least responsive to it, whereas the extrapolation of a regime of tolerance from a low number of recorded sodomy cases relies on negative evidence alone (unlike in Berlin, for example, as mentioned above, where tolerance as policy was historically documented). In the interpretation I propose, the dichotomy between state and individual, along with the narrative of oppression and resistance, becomes more complicated. Police discretion is jarring evidence of the agency of the individuals charged with operationalising the abstract state's laws and the vision of order held by its higher charges. Furthermore, the constraints on this discretion remind us that constables are themselves subjects of the state as well as its executors. Finally, as I hope to establish, one plausible reading of the spatial patterns reflected in the few known instances of street-level sexual policing targeting queer men in late Imperial St. Petersburg is that police discretion could serve an instrumental function that is by no means at odds with the mandate of policing. 
Police discretion, as a complication of cruder models of sexual oppression, has attracted some attention in discussions of Western cities. Historians including Harry Cocks, Matt Houlbrook, and George Chauncey have drawn attention to patterns of police discretion that reveal not just gaps in surveillance, but also limits and constraints on disciplinary power (Chauncey, 1994; Cocks, 2003; Houlbrook, 2005). Cocks signally describes such patterns as an inconsistency in the process of law enforcement, complicating the straightforward dichotomy between constables and queer men (2003). By virtue of these patterns, the police, most importantly, become active participants in the disciplinary construction of urban space, rather than being impersonal agents of an abstract surveillance state. Police discretion may be at the heart of an historically overlooked dialogue between constables, suspected offenders and the administrative hierarchy. As I have attempted to demonstrate, this dialogue deserves historical attention and can be easily obscured by a more traditional emphasis on the narrow enforcement of anti-sodomy laws and histories of queer oppression or tolerance.

In looking at this dialogue in the broader context of urban spatial governance, Laura Engelstein suggests that St. Petersburg offers an opportunity to test the Foucauldian model of the disciplinary society. As described above, she offers several convincing reasons for finding this model wanting (Engelstein, 1993). I propose, however, to move beyond asserting the ultimate failure of Foucault's model of the disciplinary society in explaining the nature of administrative and legislative power in Imperial Russia. Instead, I propose to cure its deficiencies by combining it with an adapted version of Foucault's parallel construction of the police as an 'arbiter of illegalities' (Foucault, 2015).

As the cases of Zimmel and Kuzmin and the fate of the secret directive of 1910 suggest, constables could act quickly and efficiently to arrest one supposedly queer man on a central street, using administrative expedients to enforce a vision of spatial order communicated by their superiors, while consistently turning a blind eye to homosexual cruising in a nearby park and passively resisting orders from the city's chief of police to expand their mandate in queer sexual policing. No evidence suggests that the discretion employed by constables in these instances was either collusive, oppressive or arbitrary. In fact, a broader context of other administrative 
efforts targeting male homosexual sex and socialisation and further cases of queer sexual policing lend weight to the possibility that these instances may not be the exception to the rule in the functioning of the law-enforcement machine, but rather a critical instrument, perhaps the critical instrument, in managing the queer urban environment and projecting state authority on the city's spaces. The goal of such policing in these cases was neither necessarily to extract illicit benefits such as sex or bribes, nor to detect and punish a blatant breach of law and morality, but instead to constrain certain kinds of activity and people in certain places and at certain times that is, to manage the urban environment, including its sexual economy and queer spaces. In the resulting 'economy of illegalities' it was, therefore, as predictable and reasonable to see a well-documented instance of sex between two men go unpunished, as it was to see a man described as a 'pederast' banished from the city for the ostensible crime of soliciting. The reflexive relationship between constables, the subjects of policing and the police hierarchy outlined in this paper as a possible factor shaping the projection of state authority onto city spaces contrasts with both the highly abstracted Foucauldian models of collusive or coercive policing, as well as a historical view of the tsarist police in late Imperial St. Petersburg as primarily inefficient and secondarily 'tolerant' of consensual homosexual sex.

This modified historical hypothesis and theoretical model based on taking seriously the historical evidence of police discretion is one that emphasises the critical role of street-level constables in the spatial projection of administrative power. This role is realised in the dialogue between what Foucault calls the impersonal machinery of the state' and its subjects - except that this 'impersonal machinery' was not, in fact, quite so impersonal (1991, p. 253). While Foucault acknowledges that the police, in occasionally colluding with citizens, granted 'a little extra life - and, by doing so, suppl[ied] the state with a little extra strength', in his description discretion appears as merely another ruse of power and one of many tools in the service of the disciplinary state $(2002$, p. 319). In addressing this apparent reductionism in Foucault's view of the disciplinary society, I suggest replacing the idea of collusion with those of discretion, compromise and constant multi-lateral negotiation, as entertained by Foucault himself in his 1973 lecture on police complicity to rampant law-avoidance by the weavers' guild in eighteenth 
century France, in which he described the police as 'arbiter in an economy of illegalities' (Foucault, 2015, p. 145; Markus \& Farmer, 2007, p. 2). The resulting model fits remarkably well with queer sexual policing in Imperial St. Petersburg.

Since, as Foucault argues, power is not a possession but a relationship, the reflexive relationships between queer men, constables, member of the police hierarchy and the general public required constables to preserve and exercise a degree of power precisely by making compromises tailored to particular situations and negotiating their mandate both with their subjects and their superiors. By functionally replacing collusion with a multi-lateral compromise involving, among other aspects, the spatial scoping of the police's mandate, we not only create a framework that can be applied to the instances of policing described above, where it is far from evident that constables extracted illicit gain or favours, but we also constructively broaden the scope for application of Foucault's concept of an economy of illegalities.

\section{Conclusion}

This paper has assembled a fragmentary but composite image of queer policing in late Imperial St. Petersburg based on seemingly unrelated events. These events are reflected in the police records of Imperial St. Petersburg - from the arrest of Ludvig Zimmel for solicitation and constables' restraint vis-à-vis recognizably queer 'cruising' behavior in one of the city's public parks, to the administrative fate of apparently straightforward instructions contained in the secret police directive of 1910 to crack down on men engaging in homosexual sex and socialization in private apartments. These newly discovered archival materials shed light on the different ways in which constables engaged with queer subjects, and the modalities of making the project of queer policing work in the city. Zimmel's story displays a procedurally efficient attempt to manage queer behavior in public spaces. By arresting Zimmel for soliciting, the constables enabled his removal from the street via a simplified court procedure. Zimmel's case stands in pointed contrast to the aims of the secret directive, which referred to an invisible source of disorder in private apartments and would have required a significantly greater effort to address. Indeed, it seems that at 
least in several boroughs no action was taken. The directive's failure may well be the result of its overweening ambition. It is remarkable both for the fact that tacit disobedience seems to have remained without administrative consequence, as well as for the document itself, which reinforces the view that constables were expected to exercise judgment and discretion in sexual policing. Finally, the story of Kuzmin's 'gang' as he called it, suggests that constables monitoring the Tavricheskii Garden exercised discretion in managing a specific public space where at least certain kinds of visible and recognizable queer socialization were tolerated.

I have tried in particular to illuminate certain otherwise obscure aspects of the policing of homosexuality, such as the diverse reactions of street-level constables to orders to penetrate the homosexual milieu by identifying suspected homosexuals and their apartments, or the use of ambiguous statutes as a convenient mode of dealing with individuals denounced as queer. These cases have been selected as illustrations of complementary aspects of compromise and discretion, which are so central to an understanding of queer policing beyond the traditional model of law enforcement in the disciplinary society. This is a practice all too easily overlooked by urban historians focusing on sexual crimes and law enforcement in the modern-day sense, or indeed committed to now classic narratives of gay oppression, resistance, and visibility. In the context of this practice of queer policing, constables played the crucial role of 'arbiters of illegalities', to borrow, extend, and critique Foucault's argument. Where Foucault describes the police as an arbiter in some historical circumstances, but characterized the relationship between criminals or deviants and constables as collusive, we need to recognize the full implications of discretionary power. Constables' practices in their relationships with queer men include elements that did not constitute collusion, in the sense of bribery or the extraction of sexual favors, but which may have been discreetly effective in attaining the objective of managing the queer urban environment to the satisfaction of the urban authorities and morality campaigners, insisting upon a degree of apparent order, decorum and public decency in the city's public spaces, without indulging in an impossible and inhumanely exhaustive policing of queer sexuality. 
What these cases suggest is not so much the disciplinary power and ambition of the state when it comes to the policing of illicit sexuality, as the utility of focusing on the role of compromise and discretion as inevitable consequences of the encounter between queer men and the men on the beat. Even in this famously authoritarian society, the limits to the 'eye of power' are obvious. There is a temptation, inevitably, to see this merely in the thematic of 'resistance', though this both simplifies and essentialises the dyad of police and queer man, and contributes little to our understanding of the police's responses at the local street and administrative court levels. Nor should we be led to see apparent tolerance as just another ruse of power, the regulation of an 'economy of illegalities' that serves the interests of the state. Instead of focusing on the traditional triad of discipline, resistance, and tolerance, this paper has made a case for looking towards discretionary power not as a marginal complement to, but as a central facet of disciplinary policing in this imperial city.

The possibility of a systematic link between police discretion and the spatial projection of state authority onto urban space may be particularly relevant for histories of queer sexual policing and has received scant attention from queer urban historians. Focusing overwhelmingly on Western experiences, several mention discretion and contingency in policing homosexual practices, but the reflexive relationships between constables, the administrative hierarchy and queer men is neglected (Bech, 1997; Boyd, 2003; Cocks, 2003; Higgs, 1999; Houlbrook, 2005; Maynard, 1994). Instead, a pervasive tendency to de-personalize laws and regulations as 'the state' seems to be the almost necessary consequence of a focus on queer subjects in the academic discussion regarding the history of queer sexual policing. This approach obviated the need for any attempt to describe the manner in which the historically readily accessible laws and regulations were operationalized by low-ranking constables vis-à-vis queer men. In the instances, where known practice obviously failed to coincide with legal order, anachronistic concepts of tolerance or haphazard inefficiency provided a convenient alternative. If one's interest, however, extends beyond the highly generalized question of degrees of oppression to, for example, the manner in which the state sought and managed to project visions of moral order onto the city and its queer milieu, then the thresholds of this tolerance 
are precisely what should be in focus. These thresholds, I maintain, are the results of a compromise between constables, members of the police hierarchy, queer men, and other parties. A history of queer sexual policing would necessarily remain incomplete - to the degree of being defective - without a practical understanding of these thresholds. To maintain norms of order and decorum, even if these deviated from the letter of the law, constables had to interpret the meaning attributed to these norms by higher-ranking authorities and negotiate this interpretation with the urban population.

By developing one strand of Engelstein's critique of the Foucauldian discursive hypothesis, it is possible to argue that court precedent and laws, unless informed by an understanding of the methods and manners of the individuals on the front line of their enforcement, are an insufficient empirical basis for a discussion of the historical trajectory of urban sexual policing and the projection of state authority onto the city's spaces more generally. To inform and extend such a discussion, I have proposed to lift the lid on the transmission box between state and civil society, between law and order, between the higher levels of the administrative hierarchy and queer men, and reveal not cogs and grit inside, but agents making broadly consistent and far from trivial decisions. An analysis of the surviving evidence of specific instances of queer sexual policing provides an opportunity to move beyond Foucault's view of police collusion and recognize patterns of police discretion and compromise as perhaps the defining aspect shaping the projection of a vision of order held by the administrative hierarchy onto the city's spaces.

\section{Disclosure statement}

No potential conflict of interest was reported by the author.

\section{Notes}

\footnotetext{
${ }^{1}$ By 'constable' I refer to three types of constables, constituting the low-ranking police force in Imperial St. Petersburg: osobiî nadziratil' (the best translation is 'special guard'), politseîskiî pristav ('police constable'), and gorodovoî ('patrolman'); see (Vysotskiî, 1903).
} 
2 The discussion is limited to sex and homosexual socialization between men, since sex between women was not criminalized.

${ }^{3}$ My understanding of the urban milieu of late Imperial St. Petersburg is based on the large available body of studies of everyday life in urban Russia, especially about disorder, deviance and anxieties. Particularly relevant to my discussion are works of Joan Neuberger, Louise McReynolds, Mark Steinberg, Susan Morrissey, and Catriona Kelly's and David Shepherd's edited collection (Hasegawa, 2017; Kelly \& Shepherd, 1998; L. McReynolds, 1992; L. McReynolds, 1994; Morrissey, 2007; Neuberger, 1993). Most scholars of Russian urban life in the late imperial period, and not least the capital St. Petersburg, would find the stereotype of Russian authoritarianism and social discipline to be just that: a stereotype. Russian society was under-governed and often close to being out of control; disorder and deviance were ubiquitous in everyday urban life; indeed that was the source of much anxiety about public life, including sexual life, even to the point of a moral panic in the years between 1906 and 1914.

${ }^{4}$ See, for example, in Matt Houlbrook's book Queer London where a police officer is cited as saying the crime was virtually undetectable (Houlbrook, 2005, p. 22)

5 I reviewed correspondence and archival files of boroughs and precincts (TSGIA SPb, Fond \#1648), the police investigative department (TSGIASPb, Fond \#965) and the police chief's central administrative apparatus (TSGIASPb, Fond \#569) for the period from 1883 to 1917.

${ }^{6}$ Reference is to local city archives as opposed to national archives containing central government files.

7 98\% of City Magistrate Court and the Police Department archives in TSGIA SPb were lost, see https://spbarchives.ru/web/group/information_resources/-/archivestore/guide_page/2141, assessed on 24 February 2017;

8 Here, Healey refers to (Pîatnitskiî, 1910 p. 88) and (Tarnovskiî, 1885, p. 72), citing Tarnovskiî: 'at the beginning of the 1870's, one of Petersburg's highest administrative figures was found guilty of pederasty and was swiftly removed from his post and exiled abroad without hearing or publicity' (Healey, 2001, p. 93 - 94). The term 'administrative punishments' as used by Healey is not obviously a reference to the civil or administrative code, which has a formal meaning. Similarly, the Russian verb used by Tarnovskiî and translated as 'found guilty' is ambiguous, meaning also 'exposed', and may not be a reference to a legal verdict in the context. The words translated by Healey as 'exiled abroad' are more literally translated as 'expelled beyond the boarder' or 'sent out beyond the 
boarder', meaning, quite plausibly, that the measure may have been temporary and could also have been a foreign appointment. Given the clarification that this person's removal from his domestic post and expulsion or transfer took place 'without hearing or publicity', it is consistent with the Russian text that the 'administrative punishment' in question was in fact not a sentence under an administrative or petty crimes statute, but rather the standard remedy of a legally non-binding yet socially compelling recommendation to remain abroad for a while or accept a foreign posting.

${ }^{9}$ The civil or administrative code (Ustav o Nakazaniîakh, Nalagaemykh Mirovymi Sud'îami, Svod Zakonov Rossiîiskoî Imperii) regulated civil offenses (grazhdanskie dela) or petty crimes and pertained to offenses carrying a maximum sentence of one-and-a-half years of jail (or equivalent) or a fine up to 300 Rubles. Prosecution was subject to reduced procedural requirements compared to prosecution under the criminal code (Ulozhenie o Nakazaniîakh I Isprvitel'nykh), see (Gromov, 1909, p. 667).

10 Responses from three boroughs (Narvakaîa, Liteînaîa, and Spassakaîa), including, fortunately, the replies of constables from almost all precincts in these boroughs, have survived. Unfortunately, responses from other eleven boroughs appear neither in the archival files of boroughs and precincts nor in those of the police chief's central administrative apparatus or the police investigation department.

11 Sodomy with a minor, accompanied by assault, or with an individual in an inferior position, such as one's domestic servants, was more likely to be persecuted than consensual sex between men (Healey, 2001, pp. 95, 96) and his references \#85 and \#87 in chapter 3; For not-previously-cited cases supporting these observations see also: (TSGIA SPb F.965, 0.1, d.1862, 1901; TSGIA SPb, F.1648, o.1, d.566, 1866 - 1915, 1913, register number 68, 3 September 1913; GARF, F.124, o.28, d.686, 1910; GARF, F.124, o.30, d.1481, 1912; GARF, F.124, 0.31, d.1026, 1913) Notably, the observation in (Healey, 2001, p. 95) that 'police rarely figure as initiators of arrests. Rather, they acted when a denunciation was received or other circumstances drew their attention to a particular "pederast" would be neither peculiar to St. Petersburg, nor conclusive regarding police activity beyond immediate enforcement of articles 995 and 996 of the criminal code banning male sodomy. 


\section{Bibliography}

\section{Primary Sources}

Tsentral'nyî Gosudarstvennyî Istoricheskiî Arkhiv, Sankt-Peterburg. St. Petersburg Russian State Historical Archive (TSGIA SPb):

TSGIA SPb, Fond 956, opis1, delo 1614 [hereafter F.\#,o.\#,d.\#], O pedaraste Ludvige Adamoviche Zimmele, 24 September 1900- 15 September 1901.

TSGIA SPb, F.1648, o.1, d.418, Kniga zapisi zaderzhannykh lits, 1910;

TSGIA SPb, F.965, o.3, d.72, Ob obkhodakh politseîskimi agentami tsentral'nikh ulits Peterburga, vokzalov, sadov, i drugikh mest poseshcheniîa publikoî v nochnoe vremîa c tsel'îu zaderzhaniîa podozritel'nykh lits i narushiteleî blagochiniîa, 1904.

TSGIA SPb, F.569, o.10, d.104, Tsirkulîary Departamenta Politsii, 1910-1914, 1910, \# 2199 on 21 October 1910, 189-90.

TSGIA SPb, F.1648, 0.1, d.1222, Tsirkulîarnye telegrammy i perepiska s Okhrannym otdeleniem ob usilenii nadzora za nastroeniem rabochikh fabrik i zavodov, za litsami sostoîashchimi pod nadzorom politsii, 1910, 48-58.

TSGIA SPb, F.1648, 0.1, d.855, Tsyrkulîary Peterburgskogo gradonachal'nika, rasporîazheniîa i perepiska s Okhrannym otdeleniem o litsakh, sostoîashchikh pod nadzorom politsii, 1910, 195.

TSGIA SPb, F.1648, o.1, d.651, Sekretnye tsirkulîary departamenta politsii i Peterburgskogo gradonachal'nika, $1866-191$. 
TSGIA SPb F.792, o.1, d.3337, Po zaîavleniîu glasnogo V.I. Likhacheva o neispolnenii upravoî izdannogo v 1879 obîazatel'nogo postanovleniîa o banîakh, 1882 - 1887.

TSGIA SPb F.965, o.1, d.1862, Po Zhalobe Kol. Sekr, Sarkisova na poruchka Paîkovskogo, zarazivchshegosîa Sifilisom, 1901;

TSGIA SPb, F. 965, o. 1, d. 1631, Po anonimy o besporîadkakh i krazakh, sovershaemykh v tavricheskom sadu vo vremîa gulîaniî, 1900.

TSGIA SPb, F.1648, o.1, d.566, Kniga zapisi ugolovnykh obvneniî, 1866 - 1915, Protokol po zaîavleniîu kr. Smolenskoî gub. Elizavety Vasil'evny Orlikovoî (Fontanka 28) o snoshenii ee muzha, Vasiliîa Nikifirova Orlikova s ego plimîannikom Pavlom Alekseevichem Kurochkinym, prozhivaîushchim u nego, 1913, register number 68, 3 September 1913;

Gosudarstvennyî Arkhiv Rossiiskoî Federatsiii. State Archive of Russian Federation, Moscow (GARF)

GARF, F.111, o.1. d.2999, Poseshchenie restoranov, 1911.

GARF, F.124, o.28, d.686 Delo po prosheniîu K.V. Sizykh o pomilovanii ee syna A. Sizukh, osuzhdennogo Irkutskim Okruzhmym sudom 11 marta 1910 goda po st. 995 i 996 Ulozh. O nakaz., 1910;

GARF, F.124, o.30, d.1481, Delo po prosheniîu I. Minîaylo, osuzhdennogo Ekaterinodarskim okruzhnym sudom po st 995, 2 p. Ulozh. o nak. o pomilovanii, 1912;

GARF, F.124, o.31, d.1026, Delo po prosheniî V. Pudenko, osuzhdennogo Rostovskim-na-Dony okruzhnym sudom po st. 152, 995, 996, i 1642 v 1910 - 1913, ob otbytii sroka nakazaniîa v gorode Postove-na-Donu, 1913. 


\section{Newspapers}

Peterburgskii Listok (a), Stolichnaîa nakip’, 11 February 1900, № 41.

Peterburgskii Listok (b), Passazh v budushchem, 2 April 1900, № 91.

Peterburgskii Listok, Mimokhodom, 1 October 1901, № 269.

Peterburgskiî listok, Nadzor za Sadami, 15 May 1909, № 131.

\section{Secondary Sources}

Beachy, R. (2014). Gay Berlin. Birthplace of a Modern Identity. New York: Vintage Books.

Bekhterev, V. (1915). O polovykh izvrashcheniîakh, kak patologicheskikh sochetatel'nykh refleksakh. Obozrenie Psikhiatrii, 7-9, 1-26.

Bernstein, L. (1995). Sonia's Daughters: Prostitutes and Their Regulation in Imperial Russia. Berkeley and Los Angeles: University of California Press

Budkov, M. M. (1910). Sbornik Obîazatelnykh Postanovleniî dlîa Goroda S.Petersburga i Prigorodnykh Politseîskikh Uchastkov: c Prilozeniem Pravil i Raz'îasneniî. St. Petersburg: Tipografiîa Peterburgskogo Gradonachal'stva.

Chauncey, G. (1994). Gay New York. Gender, Urban Culture, and the Making of the Gay Male World 1890-1940. New York: BasicBooks.

Cocks, H. (2003). Namelss Offences: Homosexual Desire in the 19th Century. London: I.B. Tauris.

Cook, M. (2003). London and the Culture of Homosexuality, 1885-1914. Cambridge: Cambridge University Press.

Croix, S. S. d. I. (2012). Chicago Whispers. A History of LGBT Chicago Before Stonewall. Wisconsin: The University of Wisconsin Press.

Daly, J. W. (2004). The Watchful State: Security Police and Opposition in Russia 1906 1917. DeKalb: Northern Illinois University Press.

Del, M. V. (1908). Sbornik Instruktsiî, Zakonopolozheniî i Rasporîazheniî dlîa Nizhnikh Chinov Politsii i Politseîskikh Urîadnikov. St. Petersburg: Tipografiîa Ministerstva Vnutrennikh Del

Engelstein, L. (1992). The Keys to Happiness. Sex and the Search of Modernity in Finde-Siecle Russia. Bloomington: Cornell University Press. 
Engelstein, L. (1993). Combined underdevelopment: discipline and the law in Imperial and Soviet Russia. The American Historical Review, 98(2), 338-353.

Engelstein, L. (1995). Soviet policy toward male homosexuality. Journal of Homosexuality, 29(2-3), 155-178.

Fedorov, A. (1896 ). Deîatel'nost' S.-Peterburgskogo vrachebno-politseîskogo komiteta za period 1889-1895 gg. Vestnik Obshchestvennoî Gigieny, Sudebnoî i Prakticheskoî Meditsiny, 11, 178 -194.

Foucault, M. (1978). The History of Sexuality: an Introduction (Vol. 1). New York

Foucault, M. (1991). Discipline and Punish: The Birth of the Prison. London: Penguin Social Sciences.

Foucault, M. (2002). "Omnes et singulatim": toward a critique of political reason. In J. D. Faubion (Ed.), Michel Foucault. Power. Essential Works of Foucault 1954 - 1984 (Vol. 3, pp. 298-325). London: Pinguin Books.

Foucault, M. (2015). 21 February 1973. In A. I. Davidson (Ed.), The Punitive Society: Lectures at the Collège de France 1972-1973, translated by Graham Burchell (pp. 139-154). Houndmills, Basingstoke: Palgrave Macmillan.

Fuks, I. B. (1914). Gomoseksualizm Kak Prestuplenie. Îuridicheskiî i UgolovnoPoliticheskiî Ocherk. St. Petersburg: Tip. t-va 'Obshchestvennaîa pol'za'.

Gromov, N. A. (Ed.) (1909). Zakony Ugolovnye. Ulozhenie o Nakazaniiakh Ugolovnykh i Ispravitel'nykh, Ustav o Nakazaniîakh, Nalagaemykh Mirovymi Sud'îami. St. Petersburg Izdatel'stvo Ministerstva Vnutrennikh Del.

Hasegawa, T. (2017). Crime and Punishment in the Russian Revolution. Mob Justice and Police in Petrograd Cambridge, Massachusetts: The Belknap Press of Harvard University Press.

Healey, D. (2001). Homosexual Desire in Revolutionary Russia: the Regulation of Sexual and Gender Dissent. Chicago: The University of Chicago Press.

Houlbrook, M. (2005). Queer London. Perils and Pleasures in the Sexual Metropolis, 1918 - 1957. Chicago: University of Chicago Press.

Il'ich, B. B. (1907). Torguîushchie Telom. Ocherki Sovremenoi Prostitutsii. Moscow: Krumbîugel'.

Karlinsky, S. (1989). Russia's gay literature and culture: the impact of the October revolution. In M. V. M. Duderman, \& J. G. Chauncey (Ed.), Hidden from 
History: Reclaiming the Gay and Lesbian Past (pp. 347-364). London: Penguin Books.

Kelly, C., \& Shepherd, D. (1998). Constructing Russian Culture in the Age of Revolution. Oxford: Oxford University Press.

Kleîgel's, N. V. (1905). Osnovy Politseîskoî Sluzhby. St. Petersburg: Tipografiîa Spb. Gradonachal'nika.

Kleîgel's, N. V. (1900). Posobie dlîa Podgotovki na Dolzhnosti Klassnye i Okolotochnykh Hadzerateleî S.-Petersburgskoî Stolichnoî Politsii. . St. Petersburg: Tip. SPB Gradonachal'stva.

Koffin'on, A. (1908). Izvrashchennyî Mir. Moscow: Tipo-Litografiîa Torgovogo doma E. Konovalova i Ko.

Koni, A. F. (1912). Na Zhiznennom Puti. Iz Zapisok Sudebnogo Deîatelîa. Zhiteîskie Vstrechi (Vol. 1). St. Petersburg: Tipografiîa T-va "Trud".

Kuzmin, M. (2000). Dnevnik, 1905-1907. St. Petersburg: Izdatel'stvo Ivana Limbakha .

Markus, D., \& Farmer, L. (2007). Introduction: regarding criminal law historically. In D. Markus \& L. Farmer (Eds.), Modern Histories of crime and punishment (pp. 1-13): Stanford University Press.

Maynard, S. (1994). Through a hole in the lavatory wall: homosexual subcultures, police surveillance, and the sialectics of discovery, Toronto, 1890-1930. Journal of the History of Sexuality, 5(2), 207-242.

McReynolds, L. (1992). St. Petersburg's" Boulevard" Press and the Process of Urbanization. Journal of urban history, 18(2), 123-140.

McReynolds, L. (1994). Urbanism as a Way of Russian Life. Journal of urban history, $20(2), 240-251$.

McReynolds, L. (2007). St. Petersburg. The national destiny in the cityscape. Journal of urban history, 33(5), $857-863$.

Merzheevskiî, V. O. (1878). Sudebnaîa Genikologiîa Dlîa Vracheî i l̂uristov. St. Petersburg: Izdanie B.G. Îanpol'skogo.

Morrissey, S. K. (2007). Suicide and the Body Politic in Imperial Russia. . Cambridge: Cambridge University Press.

Nabokov, V. D. (1903). Ėlementarnyî Uchebnik Osobennoî Chasti Russkogo Ugolovnogo Prava (Vol. 1). St. Petersburg: Senatskaîa tipografiîa. 
Neuberger, J. (1993). Hooliganism: Crime, Culture, and Power in St. Petersburg, 19001914 (Vol. 19): Univ of California Press.

Obolenskiî, P. S. (1914). Sbornik Obîzatelnykh Postanovleniî dlîa Petrograda i Prigorodnykh Politseîskikh Uchastkov. Petrograd

Obolonskiî, N. (1898). Izvrashchenije Polovogo Chuvstva. Kiev: Tipographija Impiratorskogo Universiteta.

Peniston, W. A. (2001). Pederasts, prostitutes, and pickpockets in Paris of the 1870s. Journal of Homosexuality, 41(3-4), 169-187.

Petri, O. (2016). At the bathhouse: municipal reform and the bathing commons in late imperial St. Petersburg. Journal of Historical Geography, 51, 40-51.

Pîatnitskiî, B. I. (1910 ). Polovie Izvrashcheniîa i Ugolovnoe Pravo. Mogilev: Tipografiîa I. B. Klaza.

Ruadze, V. (1908). K Sudu! Gomoseksual'niî Peterburg. St. Petersburg: Kommercheskaîa Tipografiîa Vilenchik.

Serbskiî, V. P. (1900). Sudebnaîa Psikhopatologiîa. Lektsii, Chitannye v Imperatorskom Moskovskom Universitete. Vypusk vtoroî. Klinicheskaîa psikhiatriîa. Moscow: Izd. M. i S. Sabashnikovykh.

Surh, G. D. (1989). 1905 in St. Petersburg. Labor, Society, and Revolution. Stanford: Stanford University Press.

Tarnovskiî, V. M. (1885). Izvrashchenie Polovogo Chuvstva, Sudebno-Psikhiatricheskiî Ocherk. St. Petersburg.

Volkov, V. V. (1914). Postateînyî Ukazatel' Podsudnosti Ugolovnykh Del, Predusmotrennykh Ulozheniem o Nakazaniîakh, Ugolovnym Ulozheniem i Ustavom o Nakazaniîkh, dlîa Obshchikh, Mirovykh i Volostykh Sudakh po Zakonu o Preobrazovanii Mestonogo Suda. St. Petersburg: Tip. inzh. G.A. Bernshteîna.

Weissman, N. (1985). Regular police in Tsarist Russian, 1900 - 1914. Russian Review, 44(1), 45-68.

Zuckerman, F. S. (1996). The Tsarist Secret Police and Russian Society, 1880-1917. New York: New York University Press. 